\title{
Contribution of Downregulation of L-type Calcium Currents to Delayed Neuronal Death in Rat Hippocampus after Global Cerebral Ischemia and Reperfusion
}

\author{
Xiao-Ming Li, Jian-Ming Yang, De-Hui Hu, Feng-Qing Hou, Miao Zhao, Xin-Hong Zhu, Ying Wang, Jian-Guo Li, \\ Ping $\mathrm{Hu}$, Liang Chen, Lu-Ning Qin, and Tian-Ming Gao \\ Department of Anatomy and Neurobiology, Southern Medical University, Guangzhou 510515, People’s Republic of China
}

\begin{abstract}
Transient forebrain ischemia induces delayed, selective neuronal death in the CA1 region of the hippocampus. The underlying molecular mechanisms are as yet unclear, but it is known that activation of $\mathrm{L}-\mathrm{type} \mathrm{Ca}^{2+}$ channels specifically increases the expression of a group of genes required for neuronal survival. Accordingly, we examined temporal changes in L-type calcium-channel activity in CA1 and CA3 pyramidal neurons of rat hippocampus after transient forebrain ischemia by patch-clamp techniques. In vulnerable CA1 neurons, L-type $\mathrm{Ca}^{2+}$-channel activity was persistently downregulated after ischemic insult, whereas in invulnerable CA3 neurons, no change occurred. Downregulation of L-type calcium channels was partially caused by oxidation modulation in postischemic channels. Furthermore, L-type but neither $\mathrm{N}$-type nor $\mathrm{P} / \mathrm{Q}$-type $\mathrm{Ca}^{2+}$-channel antagonists alone significantly inhibited the survival of cultured hippocampal neurons. In contrast, specific L-type calcium-channel agonist remarkably reduced neuronal cell death and restored the inhibited channels induced by nitric oxide donor. More importantly, L-type calcium-channel agonist applied after reoxygenation or reperfusion significantly decreased neuronal injury in in vitro oxygen-glucose deprivation ischemic model and in animals subjected to forebrain ischemia-reperfusion. Together, the present results suggest that ischemia-induced inhibition of L-type calcium currents may give rise to delayed death of neurons in the CA1 region, possibly via oxidation mechanisms. Our findings may lead to a new perspective on neuronal death after ischemic insult and suggest that a novel therapeutic approach, activation of L-type calcium channels, could be tested at late stages of reperfusion for stroke treatment.
\end{abstract}

Key words: calcium channels; ischemia; neuronal death; oxidation; hippocampus; rat

\section{Introduction}

The vulnerability of neurons to cerebral ischemia varies widely among different regions in the CNS. Different neuronal populations within a brain region also show different susceptibility to ischemic insult. Studies have shown that CA1 pyramidal neurons in hippocampus are particularly vulnerable to ischemic insult and die 3-7 d after transient forebrain ischemia, whereas CA3 neurons are relatively resistant to transient ischemia and remain viable (Pulsinelli et al., 1982; Kirino et al., 1984). Although the mechanisms underlying selective neuronal damage are not understood, there is evidence that cell death a few days after a transient ischemia follows from $\mathrm{Ca}^{2+}$ overload (Choi, 1995; Kristian and Siesjo, 1998; Bano et al., 2005). This hypothesis has received support from experiments made during the period of ischemia

Received 0ct. 7, 2006; revised April 9, 2007; accepted April 11, 2007

This work was supported by National Nature Science Foundation of China Grants 30330240 and U0632007, National Basic Research Program of China Grant 2006CB504100, Key Project of Guangdong Province Grant 2006A36001003, and by a Cheung King Scholars Programme to T.-M.G. We thank Drs. J. G. Nicholls, L. Mei, and S. G. He for insightful suggestions and critical reading of this manuscript.

Correspondence should be addressed to Dr. Tian-Ming Gao, Department of Anatomy and Neurobiology, Southern Medical University, Guangzhou 510515, People's Republic of China. E-mail: tgao@fimmu.com.

X.-M. Li's present address: Institute of Molecular Medicine and Genomics and Department of Neurology, Medical College of Georgia, Augusta, GA 30912.

D0I:10.1523/JNEUROSCI.0802-07.2007

Copyright $\odot 2007$ Society for Neuroscience $\quad$ 0270-6474/07/275249-11\$15.00/0 and immediately afterward (Andine et al., 1992; Silver and Erecinska, 1992). However, the short-lived elevation of $\mathrm{Ca}^{2+}$ is difficult to reconcile with the onset of CA1 neuronal death that manifests itself days later.

Voltage-gated $\mathrm{Ca}^{2+}$ channels have a central role in dendritic development, neuronal survival, and synaptic plasticity and are essential for converting electrical activity into biochemical events in brain (Berridge, 1998). Neurons express at least nine types of voltage-gated $\mathrm{Ca}^{2+}$ channels that are specialized for different functions (Catterall, 2000). Within the hippocampus and other brain regions, $\mathrm{L}$-type $\mathrm{Ca}^{2+}$ channels are prevalent, contributing $\sim 30-50 \%$ of total calcium current (Regan et al., 1991), and activation of the L-type $\mathrm{Ca}^{2+}$ channel effectively triggers transcription factors such as the cAMP response element-binding protein (CREB) and MEF-2 (myocyte enhancer factor 2) and specifically increases the expression of a group of $\mathrm{Ca}^{2+}$-regulated genes, including those encoding c-Fos, brain-derived neurotrophic factor (BDNF), and Bcl-2, that have been shown to be required and important for neuronal survival (Murphy et al., 1991; Bito et al., 1996; Catterall, 2000; Dolmetsch et al., 2001; West et al., 2001; Weick et al., 2003; Zhou et al., 2004). Overactivation of L-type calcium channels has been shown to contribute significantly to declining viability of hippocampal neurons during aging (Landfield, 1996; Norris et al., 2002). Modulation of L-type 
$\mathrm{Ca}^{2+}$ channel activity could therefore have dramatic effects on survival of pyramidal neurons and in particular might play a crucial role in the delayed neuronal death of CA1 hippocampal neurons after ischemia.

To clarify the possibility of late-developing alterations of L-type $\mathrm{Ca}^{2+}$ channels after ischemia, we have examined the temporal changes in L-type calcium-channel currents in CA1 and CA3 pyramidal neurons of rat hippocampus after transient forebrain ischemia and its possible cellular mechanisms. Moreover, the role of ischemia-induced inhibition of L-type calcium channels has been investigated in in vitro and in vivo ischemic models.

Preliminary results from these studies were presented previously in abstract form (Li et al., 2002, 2003b).

\section{Materials and Methods}

Animals. Male adult Wistar rats weighing 200-220 g was used in the present study. Food and water were ad libitum available. All experimental procedures in this study were performed within National Institutes of Health guidelines for the care and use of laboratory animals.

Transient forebrain ischemia and intracerebroventricular delivery of Bay $K$ 8644. Transient forebrain ischemia ( $15 \mathrm{~min}$ ) was induced by the use of the four-vessel occlusion method with some modification (Pulsinelli and Brierley, 1979; Gong et al., 2002). Briefly, rats were anesthetized with chloral hydrate (i.p., $35 \mathrm{mg} / 100 \mathrm{~g}$ weight), and both common carotid arteries were exposed for subsequent occlusion of these vessels. Both vertebral arteries were electrocauterized permanently. On the next day, the fully awake rats were restrained, and the carotid clasps were tightened to produce four-vessel occlusion. Severe transient forebrain ischemia was induced by occluding both common carotid arteries for $15 \mathrm{~min}$. After release of the carotid artery clasps, cerebral blood flow resumed immediately. Signs, such as unresponsiveness, loss of righting reflex, and catatonic postures, were thought to be indicative of forebrain ischemia. Rats with postischemic convulsions were excluded from study. Sham operation was performed using the same surgical exposure procedures, except that the carotid arteries were not occluded.

For intracerebroventricular delivery of Bay K 8644, animals were cannulated under chloral hydrate anesthesia with an L-shaped stainless steel cannula (Alzet brain infusion kit 1; Durect, Cupertino, CA) aimed at the left ventricle (from bregma: anteroposterior, $-0.8 \mathrm{~mm}$; lateral, $1.5 \mathrm{~mm}$; depth, $3.5 \mathrm{~mm}$ ). The cannula assembly was anchored by four stainless steel screws and embedded with Glass Ionomer Cement type II (Sankin Kogyo K.K., Tokyo, Japan). The osmotic minipumps loaded with $100 \mu \mathrm{l}$ of $2 \%$ DMSO in artificial CSF or $100 \mu \mathrm{l}$ of $2 \%$ DMSO containing Bay K $8644(0.2 \mathrm{~mm}$ ) delivered at $0.5 \mu \mathrm{l} / \mathrm{h}$ (Alzet micro-osmotic pump; model 1007D) were placed subcutaneously between the scapulas, and its outlet was disconnected with the cannula. After $4 \mathrm{~d}$ recovery, the rats were subjected to $15 \mathrm{~min}$ forebrain ischemia. $12 \mathrm{~h}$ after reperfusion, the rats were anesthetized to allow the connection of the pump to the cannula with polycarbonate tubing. The spent pumps were withdrawn after $3 \mathrm{~d}$ delivery. The rectal temperature was monitored for all animals before, during, and up to $7 \mathrm{~d}$ after ischemia, and no significant differences in rectal temperature were observed between control groups and Bay K-8644-treated group. Seven days after ischemic insult, animals were anesthetized with an overdose of chloral hydrate and perfused transcardially with saline and then with buffered $4 \%$ paraformaldehyde. The brains were postfixed for $4 \mathrm{~h}$ and then immersed in successive solutions of 10,20 , and $30 \%(\mathrm{w} / \mathrm{v})$ sucrose in phosphate buffer at $4^{\circ} \mathrm{C}$ over $72 \mathrm{~h}$. Coronal sections $(6 \mu \mathrm{m})$ were cut at the level of the dorsal hippocampus on a freezing microtome and then used for Nissl staining. The number of normal-appearing pyramidal cells in the stratum pyramidale within the CA1 field was counted using Olympus (Tokyo, Japan) BX51 microscope at a magnification of $400 \times$. Histologic analysis was performed by a blinded observer, and the average of the right and left survived cell numbers (neurons per $1 \mathrm{~mm}$ liner length) in a single section of dorsal hippocampus was calculated for each rat as reported by Kirino et al. (1984). Three sections from each animal were used for counting.

Acute dissociation procedures. Pyramidal cells in hippocampi were dis- sociated acutely from rats at 6,24 , and $48 \mathrm{~h}$ after reperfusion and shamoperated for CA1 region, 24 and $48 \mathrm{~h}$ after ischemia and sham operated for CA3 using procedures as described previously with some modifications (Gong et al., 2000). Briefly, Wistar rats were anesthetized with chloral hydrate (i.p., $35 \mathrm{mg} / 100 \mathrm{~g}$ weight) and then decapitated. Brains were quickly removed, iced, and blocked for slicing. The blocked tissue was cut into $400-\mu \mathrm{m}$-thick slices with a Vibroslice (Campden Instruments, Lafayette, IN) while bathed in a low $\mathrm{Ca}^{2+}$, HEPES-buffered salt solution containing $140 \mathrm{~mm}$ sodium isethionate, $2 \mathrm{~mm} \mathrm{KCl,} 4 \mathrm{~mm} \mathrm{MgCl}$, $0.1 \mathrm{~mm} \mathrm{CaCl}_{2}, 23 \mathrm{~mm}$ glucose, and 15 mm HEPES, pH 7.4 (300-305 $\mathrm{mOsm} / \mathrm{L})$. Slices were then incubated for $1-6 \mathrm{~h}$ at room temperature $\left(20-22^{\circ} \mathrm{C}\right)$ in a $\mathrm{NaHCO}_{3}$-buffered saline bubbled with $95 \% \mathrm{O}_{2} / 5 \% \mathrm{CO}_{2}$ containing $126 \mathrm{~mm} \mathrm{NaCl}, 2.5 \mathrm{~mm} \mathrm{KCl}, 2 \mathrm{~mm} \mathrm{CaCl}, 2 \mathrm{~mm} \mathrm{MgCl}_{2}, 26 \mathrm{~mm}$ $\mathrm{NaHCO}_{3}, 1.25 \mathrm{~mm} \mathrm{NaH}_{2} \mathrm{PO}_{4}$, and $10 \mathrm{~mm}$ glucose, $\mathrm{pH}$ 7.4, with $\mathrm{NaOH}$ (300-305 mOsm). Bathed in the low $\mathrm{Ca}^{2+}$ buffer, CA1 or CA3 region of hippocampus was dissected out under a dissecting microscope, and was further cut into $5 \sim 6$ pieces of $\sim 1 \times 1 \mathrm{~mm}$. These pieces were then placed into an oxygenated chamber containing Pronase [Sigma (St. Louis, MO) protease type XIV; $1-1.5 \mathrm{~g} / \mathrm{L}$ ] in HEPES-buffered HBSS (Sigma) at $33^{\circ} \mathrm{C}$. After 30-45 min of enzyme digestion, tissue was rinsed three times in the low-Ca ${ }^{2+}$, HEPES-buffered saline and dissociated mechanically with a graded series of fire-polished Pasteur pipettes. The cell suspension was then plated into a $35 \mathrm{~mm}$ Lux Petri dish mounted on the stage of a microscope [Leica (Nussloch, Germany) DMLFS] containing HEPESbuffered HBSS saline. After allowing the cell to settle, the solution bathing the cells was changed to our recording solution.

Electrophysiology. Recording pipettes were pulled from glass capillary tubes (Drummond Scientific, Broomall, PA) using a micropipette puller (model P-97; Sutter Instruments, Novato, CA). The resistance of cellattached patch-recording pipettes was 6-9 $\mathrm{M} \Omega$; the resistance of wholecell recording pipettes was $2-4 \mathrm{M} \Omega$. Recordings were obtained according to standard patch-clamp methods using an Axopatch 200B amplifier (Molecular Devices, Union City, CA) interfaced to a personal computer. Voltage commands were generated, and current responses were recorded and analyzed using a computerized acquisition and storage system (pCLAMP; Molecular Devices). For cell-attached patch recordings, current responses were low-pass filtered at $1 \mathrm{kHz}$ and digitized at $5 \mathrm{kHz}$. Whole-cell recordings were filtered at $2 \mathrm{kHz}$ and digitized at $2-3 \mathrm{kHz}$. Voltage pulses were delivered at $5 \mathrm{~s}$ intervals. Electrophysiological recordings were performed at room temperature $\left(21-24^{\circ} \mathrm{C}\right)$.

Recording solutions. For cell-attached single-channel patch recording, the extracellular bath solution contained the following (in mM): 140 potassium gluconate, $3 \mathrm{MgCl}_{2}$, 10 EGTA, 10 glucose, $10 \mathrm{HEPES}$, and $0.001 \mathrm{TTX}, \mathrm{pH} 7.4$, with $\mathrm{KOH}$. The recording pipette solution contained the following (in mM): $110 \mathrm{BaCl}_{2}, 10$ TEA-Cl, and 10 HEPES, $\mathrm{pH}$ 7.3, with TEA-OH. Bay K $8644(500 \mathrm{~nm})$, a potent L-type $\mathrm{Ca}^{2+}$-channel agonist, was added to the cell-attached pipette to enhance recording of L-type channels. When treated with Bay K 8644, total patch current is dominated by L-type channel current (Thibault and Landfield, 1996; Chen et al., 2000).

For whole-cell patch-clamp recordings of voltage-gated $\mathrm{Ca}^{2+}$ currents, the external solution had the following composition (in $\mathrm{mM}$ ): 90 choline chloride, 50 TEA-Cl, $5 \mathrm{BaCl}_{2}, 5 \mathrm{CsCl}, 2 \mathrm{MgCl}_{2}, 10$ glucose, 10 HEPES, pH 7.3, with TEA-OH, 0.001 TTX, $0.002 \omega$-conotoxin GVIA, $0.003 \omega$-conotoxin MVIIC, and $0.0002 \omega$-agatoxin IVA. The whole-cell recording pipette contained the following (in $\mathrm{mM}$ ): 145 methanesulfonic acid, 11 EGTA, 10 TEA-Cl, $5 \mathrm{MgCl}_{2}, 5 \mathrm{Mg}$-ATP, $1 \mathrm{CaCl}_{2}, 0.1$ leupeptin, and 10 HEPES, $\mathrm{pH} 7.3$, with $\mathrm{CsOH}$. The osmolarity of all recording solutions was adjusted to $320-325 \mathrm{mOsm}$ as necessary, by the addition of sucrose.

Single-channel recording. Single-channel conductance was estimated as the slope of the current-voltage relationship for L-type $\mathrm{Ca}^{2+}$ channels recorded with $110 \mathrm{~mm} \mathrm{Ba}^{2+}$ as the charge carrier. Current-voltage curves were generated using the current amplitude determined from Gaussian fits to amplitude histograms from individual patches. A 50\% threshold criterion was used to determine the durations of open events. Open times of L-type channels that exceeded certain duration were used to provide an estimate of single-channel amplitude. Logarithmic distributions of open durations were exponentially fitted using the least-square algo- 
rithm method. The ignored level for detecting events was limited to 300 $\mu \mathrm{s}$. Single, unobscured openings could be measured readily at more negative potentials $(-20$ to $0 \mathrm{mV})$ but were more difficult to resolve at positive steps at which numerous channel openings overlapped; however, measurable openings $(n=10)$ were obtained for each voltage at each groups. Ensemble average (pseudomacroscopic) current responses were obtained for each patch from a series of 15 depolarizing pulses (300 $\mathrm{ms}$ duration) evoked from a holding potential $\left(V_{\mathrm{H}}\right)$ of $-50 \mathrm{mV}$ to a command potential $\left(V_{\mathrm{C}}\right)$ of $-10 \mathrm{mV}$. Leak and capacitive currents were subtracted using averaged currents obtained from hyperpolarizing steps. Most patches were run through an $I-V$ series, with one evoked response at each command voltage ( $5 \mathrm{~s}$ interpulse intervals). Average total patch current $(I)$ was determined by integrating the leak-subtracted ensemble average current trace from the zero baselines to the inward current envelope during the pulse and dividing the integral by the duration of the pulse (300 ms). Open times and open probabilities were obtained from sweeps idealized with a half-amplitude crossing criterion and cubic spline interpolation. Overall open probability $\left(P_{\mathrm{o}}\right)$ in response to a particular stimulus was calculated by evaluating all applicable sweeps during the entire recording, including null sweeps. The total open time during the analyzed portion of the sweep was divided by the analysis time period. Patches that contained more than two of the same kind of channel were included in calculating average total current but were excluded in calculating open probability and open time. Pipette resistance was measured for each patch and did not vary with neurons of different groups (data not shown).

Whole-cell recording. L-type $\mathrm{Ca}^{2+}$ currents were evoked by depolarizing pulse commands $100 \mathrm{~ms}$ in duration, and except for voltage dependence studies were evoked from $V_{\mathrm{H}}$ of $-50 \mathrm{mV}$ to a series of depolarizing voltage-clamp steps or only $V_{\mathrm{C}}$ of $-10 \mathrm{mV}$. A fractional $(\mathrm{P} / \mathrm{N})$ method, using five fractionally scaled hyperpolarizing subpulses, was used to leak subtract whole-cell current traces on-line. Pipette capacitance was compensated. Series resistance and whole-cell compensation at the amplifier were not applied routinely throughout these studies, and we also confirmed that compensation does not alter the shape or amplitudes of activated currents under our conditions. Current density (in picoamperes per picofarad) was determined by dividing the mean current evoked during a depolarizing command by the cell-membrane capacitance. Data were recorded from 12 to 15 cells per group.

Western blot. The CA1 tissue of hippocampus was homogenized in Buffer A (5 mm Tris-HCl, pH 7.5, 0.32 м sucrose, $120 \mathrm{~mm} \mathrm{KCl,} 1 \mathrm{~mm}$ EDTA, $1 \mathrm{~mm}$ EGTA, $0.2 \mathrm{~mm}$ PMSF, and $1 \mu \mathrm{g} / \mathrm{ml}$ aprotinin). Cell membranes were collected by ultracentrifugation at $100,000 \times g$ for $1 \mathrm{~h}$ at $4^{\circ} \mathrm{C}$ and were resuspended in Buffer B (20 mM HEPES, pH 7.5, 10\% glycerine, 2\% Triton X-100, 1 mM EDTA, 1 mm EGTA, $0.2 \mathrm{~mm}$ PMSF, and $1 \mu \mathrm{g} / \mathrm{ml}$ aprotinin), kept on ice for $2 \mathrm{~h}$, and then the unsolubilized material was removed by centrifugation at $10,000 \mathrm{rpm}, 4^{\circ} \mathrm{C}, 30 \mathrm{~min}$. Protein concentration was measured by the Bradford method. Samples were combined with $2 \times$ SDS loading buffer, boiled for $10 \mathrm{~min}$, and loaded onto $10 \%$ polyacrylamide-SDS gel. Proteins were then transferred to a nitrocellulose membrane (Millipore, Billerica, MA) for $2 \mathrm{~h}$ at $350 \mathrm{~mA}$, and membranes were incubated in PBS containing 0.1\% Tween 20 and 5\% nonfat dried milk for $2 \mathrm{~h}$ at room temperature. After incubation with primary antibody (1:200 dilution; Alomone Labs, Jerusalem, Israel) in the same buffer for $2 \mathrm{~h}$ at room temperature, or overnight at $4^{\circ} \mathrm{C}$, the blots were washed three times in PBS containing $0.1 \%$ Tween 20 for $10 \mathrm{~min}$ and then incubated with peroxidase-conjugated goat anti-rabbit IgG for $1 \mathrm{~h}$ in PBS, $0.1 \%$ Tween 20 at room temperature. $\mathrm{Ca}_{\mathrm{V} 1.2}$ and $\mathrm{Ca}_{\mathrm{V} 1.3}$ subunits immunoreactivity was detected by chemiluminescence with ECL reagent. A negative control experiment with the corresponding antigen peptides (preincubation with the same amount of antibody for $1 \mathrm{~h}$ at room temperature) used for immunization was done to check specificity of the primary antibody.

Immunohistochemistry. $\mathrm{Ca}_{\mathrm{V} 1.2}$ and $\mathrm{Ca}_{\mathrm{V} 1.3}$ subunit distribution in $\mathrm{CA} 1$ region was assessed by immunolabeling of brain sections at the level of the dorsal hippocampus as described previously (Li et al., 2003a). In brief, the brains were immersed in $4 \%$ paraformaldehyde for $2-4 \mathrm{~h}$ and then cut into coronal sections of $30 \mu \mathrm{m}$ thickness on a freezing microtome. The free-floating sections were successively incubated with $0.3 \%$
$\mathrm{H}_{2} \mathrm{O}_{2}, 10 \%$ normal goat serum, and primary antibody (Alomone Labs) overnight at room temperature. After being washed, the sections were incubated with biotinylated goat anti-rabbit IgG and then avidin-biotin-peroxidase solution (Vectastain ABC kit; Vector Laboratories, Burlingame, CA). After three additional washes, the sections were incubated in $50 \mathrm{~mm}$ Tris- $\mathrm{HCl}, \mathrm{pH} 7.5$, for $10 \mathrm{~min}$ and treated with $0.05 \% 3,3^{\prime}$ diaminobenzidine tetrahydrochloride and $0.003 \% \mathrm{H}_{2} \mathrm{O}_{2}$ in $50 \mathrm{~mm}$ Tris$\mathrm{HCl}, \mathrm{pH}$ 7.5. The sections were dehydrated in ascending ethanol series, immersed in xylene, and coverslipped with Permount. For the assessment of nonspecific immunostaining, alternating sections from each experimental condition were incubated without the primary antibody or, in some cases, with normal calf serum before immunohistochemistry. These sections showed no labeling.

Cell culture and induction of neuronal death. Pure primary hippocampal neurons from 1-d-old (postnatal day 1) rats (Ji et al., 1998) were cultured in Neurobasal medium with 2\% B27 supplement, $0.5 \mathrm{~mm}$ glutamine, and $100 \mathrm{U} / \mathrm{ml}$ penicillin/streptomycin (Invitrogen, San Diego, $\mathrm{CA})$. Cells were grown at $37^{\circ} \mathrm{C}$ in a humidified atmosphere containing $5 \% \mathrm{CO}_{2}$ and $95 \%$ air. Cultures contain $>95 \%$ neurons as routinely controlled by neuronal-specific nuclear protein immunostaining. All experiments were performed on cells cultured for $12 \mathrm{~d}$.

Hippocampal neurons were cultured for $48 \mathrm{~h}$ with a medium containing L-type calcium-channel antagonists (nimodipine and nifedipine), $\mathrm{N}$-type channel antagonists ( $\omega$-conotoxin GVIA), P/Q-type channel antagonists ( $\omega$-agatoxin IVA), sodium nitroprusside (SNP), SNP plus nifedipine, SNP plus Bay K 8644, or Bay K 8644 for control. Sister cultures were exposed to solvent ethanol $(0.1 \%)$ alone in maintenance media. Cell viability was determined using the 3-(4,5-dimethylthiazol-2-yl)-2,5diphenyltetrazolium bromide (MTT). MTT is an indicator of the mitochondrial activity of living cells and represents a good marker of cell survival in numerous cell culture models of toxicity. In the present study, cells were exposed to high-glucose DMEM containing MTT $(0.25 \mathrm{mg} /$ $\mathrm{ml})$. After a $3 \mathrm{~h}$ incubation $\left(37^{\circ} \mathrm{C}\right)$, MTT reduction into living cells was quantified at $570 \mathrm{~nm}$ using a microplate reader (ELX800; BioTek Instruments, Winooski, VT). Data came from at least three independent experiments.

For OGD, the protocol was described in detail previously (Culmsee et al., 2005). Briefly, glucose-free Earle's balanced salt solution medium was purged with $\mathrm{N}_{2} / \mathrm{CO}_{2}(95 \% / 5 \%)$ for 30 min resulting in an oxygen content of $2-3 \%$, neurons were then washed three times with this medium and incubated for $4 \mathrm{~h}$ in an $\mathrm{N}_{2} / \mathrm{CO}_{2}(95 \% / 5 \%)$ atmosphere. Control cells were incubated in Earle's balanced salt solution with $10 \mathrm{~mm}$ glucose in a normoxic incubator for the same period. Thereafter, the medium was replaced by standard culture medium (see above). Twenty-eight hours after onset of OGD, cells were fixed with $4 \%$ formaldehyde in PBS for quantification of cell death. For studies with Bay K 8644, cells were treated with solvent alcohol $(0.1 \%)$ or Bay K $8644(0.3 \mu \mathrm{M})$ after $1 \mathrm{~h}$ of reoxygenation for $23 \mathrm{~h}$. Cells were stained with Hoechst 33342 (Sigma), fixed in $4 \%(\mathrm{v} / \mathrm{v})$ paraformaldehyde, and examined morphologically by fluorescence microscopy.

Statistical analysis. The data were expressed as mean \pm SEM and $X^{2}$ test, two-tailed Student's $t$ test or one-way ANOVA (SPSS, Chicago, IL) were used for statistical analysis. Changes were identified as significant if $p<0.05$.

\section{Results}

Downregulation of whole-cell L-calcium currents in CA1 but not CA3 neurons after ischemia-reperfusion

Whole-cell recordings were obtained from CA1 and CA3 pyramidal neurons acutely dissociated from rat hippocampus. To isolate the L-type $\mathrm{Ca}^{2+}$ current, $\mathrm{N}$ - and P/Q-type $\mathrm{Ca}^{2+}$ currents were blocked with saturating concentrations of a combination of $\mathrm{Ca}^{2+}$-channel antagonists $(2 \mu \mathrm{M} \omega$-conotoxin GVIA; $3 \mu \mathrm{M}$ $\omega$-conotoxin MVIIC; $0.2 \mu \mathrm{M} \omega$-agatoxin IVA) (Burley and Dolphin, 2000; Sochivko et al., 2003). A holding potential of $-50 \mathrm{mV}$ was used to eliminate $\mathrm{R}$-type $\mathrm{Ca}^{2+}$ current, because held at this potential $>80 \%$ of $\mathrm{R}$-type $\mathrm{Ca}^{2+}$ conductance is inactivated in rat CA1 neurons (Sochivko et al., 2003). A sustained inward current 
was activated by depolarizing voltage steps from a holding potential of $-50 \mathrm{mV}$ with $5 \mathrm{mM} \mathrm{Ba}^{2+}$ as the charge carrier. This isolated current was blocked by $\sim 90 \%$ with L-type $\mathrm{Ca}^{2+}$-channel blocker nifedipine (10 $\mu \mathrm{M}$, data not shown). Correspondingly, nearly all cells tested had similar calcium currents. Immediately after the whole-cell configuration was established, the currents were of comparable magnitude. Over the course of the next 3-5 min, the currents grew larger and eventually stabilized. After run-up, calcium currents often showed a variable rundown that proceeded much more slowly than the initial run-up. In our conditions, large inward L-type calcium currents could be recorded for at least $15 \mathrm{~min}$ without significant rundown $(<10 \%)$.

Whole-cell $\mathrm{Ca}^{2+}$ currents elicited by a series of depolarizing voltage-clamp steps from a holding potential of $-50 \mathrm{mV}$ were recorded from hippocampal CA1 and CA3 neurons of control and $24 \mathrm{~h}$ postischemic rats (Fig. $1 A, C$ ). The average current density (in picoamperes per picofarad; $-10 \mathrm{mV}$ ) was calculated for cells at each group. The average current density was $-13.65 \pm 1.48 \mathrm{pA} / \mathrm{pF}(n=15)$ and $-13.37 \pm 1.60 \mathrm{pA} / \mathrm{pF}(n=15)$ for control CA1 and CA3 neurons, respectively. By $24 \mathrm{~h}$ after reperfusion, average current density was significantly decreased to $-4.46 \pm 0.60 \mathrm{pA} / \mathrm{pF}(n=$ $15 ; p<0.01)$ for CA1 neurons, but no obvious change was observed in CA3 neurons $(-12.89 \pm 1.17 \mathrm{pA} / \mathrm{pF} ; n=15 ; p>0.05)$ (Fig. $1 B, D$ ).

\section{Persistent downregulation of single L-calcium-channel activity in CA1 but not CA3 neurons after ischemia-reperfusion}

Cell-attached recordings were made from 316 membrane patches of CA 1 and CA3 pyramidal neurons obtained from 64 adult rats. Extracellular bath solution containing $140 \mathrm{mM} \mathrm{K}^{+}$was used to zero the membrane potential during recording. The characteristics of L-type $\mathrm{Ca}^{2+}$ channels we recorded in cell-attached patches from both control and ischemic neurons are the same as those reported previously (Fisher et al., 1990): high activation threshold, no obvious inactivation, high selectivity to $\mathrm{Ba}^{2+}$, unitary conductance of $\sim 27 \mathrm{pS}$, and high sensitivity to the L-type $\mathrm{Ca}^{2+}$ channel agonist Bay K 8644 and antagonist nifedipine.

Figure 2, $A$ and $B$, shows representative current traces of L-type $\mathrm{Ca}^{2+}$ channel and average total patch current from patches of control and postischemic CA1 neurons. Average total patch current $(I)$ in patches (evoked from $V_{\mathrm{H}}=-50 \mathrm{mV}$ to $V_{\mathrm{C}}=$ $-10 \mathrm{mV}$ ) was $0.439 \pm 0.058 \mathrm{pA}$ in control cells $(n=25), 0.419 \pm$ $0.099 \mathrm{pA}$ for cells $6 \mathrm{~h}(n=23), 0.154 \pm 0.024 \mathrm{pA}$ for cells $24 \mathrm{~h}$ $(n=23)$, and $0.080 \pm 0.021 \mathrm{pA}$ for cells $48 \mathrm{~h}(n=16)$ after reperfusion, respectively, representing a persistent decrease in CA1 neurons between 24 and $48 \mathrm{~h}$ of reperfusion when compared with control $(p<0.01)$ (Fig. $2 E$ ).

At a fixed membrane potential, total patch current is determined by the single-channel unitary conductance and the open probability $\left(P_{\mathrm{o}}\right)$. To determine which of these factors might be
B

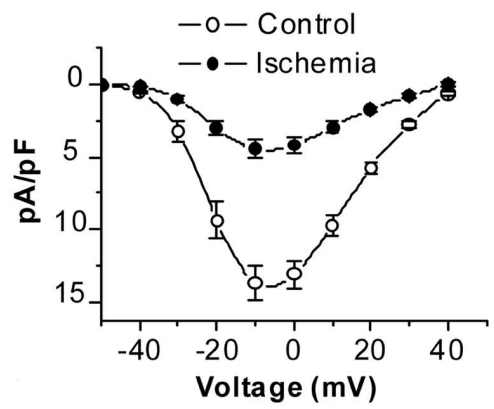

D

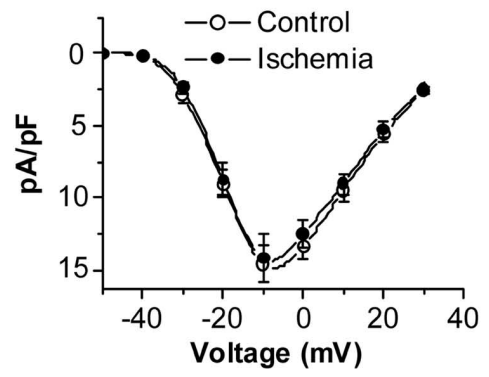

responsible for the overall change in total patch current, we first compared unitary conductance between control and postischemic channels. Single-channel amplitude was measured at multiple test voltages in patches with clearly resolvable openings; there was no difference in the single-channel amplitude at any given voltage between control and postischemic groups. In addition, the slope conductance for each patch was determined by fitting a regression line through the data. As shown in Figure $2 F$, the mean slope conductance of L-type calcium channels in the control group did not differ from that in neurons 6,24 , and $48 \mathrm{~h}$ after reperfusion ( $p>0.05 ; n=10$ for each group). In contrast, there was a significant reduction of $P_{\mathrm{o}}$ at 24 and $48 \mathrm{~h}$ after ischemia when compared with control (Fig. $2 G$ ).

To analyze the differences in voltage dependence of channel activity between control and postischemia, individual $P_{\mathrm{o}}-V$ curves were fitted by the Boltzmann equation $P_{\mathrm{o}}=P_{\max }[1+\exp$ $\left.\left(\left(V_{1 / 2}-V\right) / k\right)\right]$, where $k$ is the membrane depolarization for an $e$-fold increase in $P_{\mathrm{o}}$, and $V_{1 / 2}$ is the patch potential at which $P_{\mathrm{o}}$ is one-half of the maximum $P_{\mathrm{o}}\left(P_{\max }\right) . V_{1 / 2}$ and $k$ could be obtained by plotting $P_{\mathrm{o}} / P \max$ against membrane potential (Fig. $2 G$ ). Statistical analysis showed that there was no significant difference in $k$ values between control and postischemic groups $(p>0.05)$, whereas the value of $V_{1 / 2}$ was increased at 24 and $48 \mathrm{~h}(p<0.01)$ after ischemia when compared with control $(n=10$ for each group) (supplemental Table S1, available at www.jneurosci.org as supplemental material), indicating the changes in the threshold of channel activation without alteration of voltage dependence in postischemic channels.

Kinetic analysis of L-type calcium channels was obtained from patches in which single-channel activities were observed. At a given holding voltage, the open probability is determined by 
A

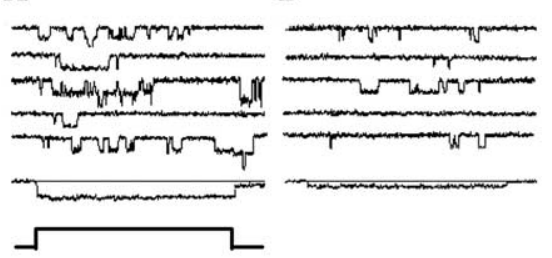

$\mathbf{E}$

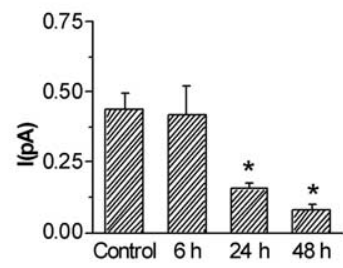

G

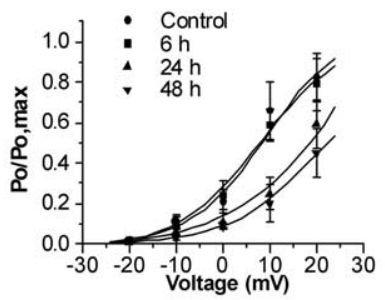

C

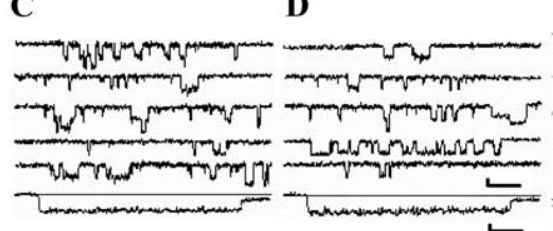

F

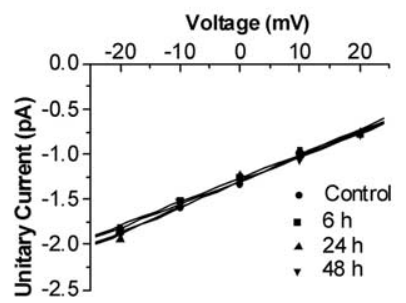

$\mathbf{H}$

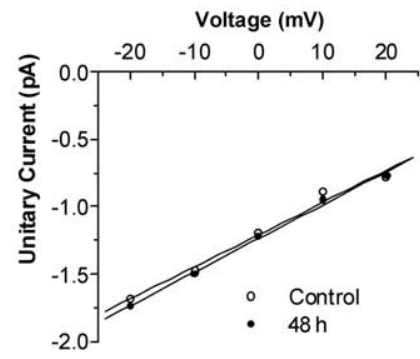

Figure 2. Persistent modification of single $\mathrm{L}_{-} \mathrm{Ca}^{2+}$-channel gating in $\mathrm{CA} 1$ but not $\mathrm{CA} 3$ neurons after ischemia-reperfusion. $A-D$, Five representative leak-subtracted recordings from cell-attached patches on $C A 1(A, B)$ and $C A 3(C, D)$ neurons of control and ischemic animals. $A, C$, Control group. $\boldsymbol{B}, \boldsymbol{D}, 48 \mathrm{~h}$ of reperfusion group during repetitive depolarizations $(-50$ to $-10 \mathrm{mV})$. All perfectly recorded patches were used to create an average total current for each group (shown below the 5 single traces). Voltage protocol is shown at the bottom. Calibration: $60 \mathrm{~ms}, 1 \mathrm{pA}$. E, Changes in average total patch current calculated by division of the integral of each ensemble average by the pulse or window duration in CA1 neurons after ischemia. Mean \pm SEM for current amplitude during the $300 \mathrm{~ms}$ depolarization from holding potential $-50 \mathrm{mV}$ to testing potential $-10 \mathrm{mV}$. ${ }^{*} p<0.01$ compared with control. $\boldsymbol{F}$, Unitary current amplitudes to multiple test voltages in patches from control and postischemic CA1 neurons. Individual values represent the mean amplitude of all clearly resolvable L-type openings during the pulse for each patch at each voltage ( $n=10$ patches per group at each voltage). Mean slope conductance for each group was calculated from the average of individual patch slope conductance. $\mathbf{G}$, Comparisons of voltage-dependent activation of L-type calcium channels in control and postischemic $C A 1$ neurons. Voltage dependence of activation represented by $P / P_{\max }$ plotted against membrane potential. Smooth curves derived from the Boltzmann relation are given by $P / P_{\max }=1 /\left\{1+\exp \left[\left(V_{1 / 2}-V\right) / k\right]\right\}$. $\boldsymbol{H}$, Unitary current amplitudes to multiple test voltages in patches from control and $48 \mathrm{~h}$ postischemic $C A 3$ neurons ( $n=10$ patches per group at each voltage).

channel open time and open frequency. To understand which is the major component contributing to the change in open probability after ischemia, kinetics of L-type calcium channels was compared between control and postischemic groups. The distributions of open times of L-type calcium channels from different groups could be fitted well by a single-exponential function. It is clear from the date summarized in Table S1 that no significant changes were observed in the open time constants of the L-type calcium channel after ischemia. However, the open frequency was persistently decreased between 24 and $48 \mathrm{~h}$ of reperfusion when compared with control $(p<$ 0.01) (supplemental Table S1, available at www.jneurosci.org as supplemental material). These results indicate a major contribution of the change in open frequency to the differences in open probability between control and postischemic groups.

To elucidate the role of L-type $\mathrm{Ca}^{2+}$ channels in the ischemiainduced selective neuronal injury, it is necessary to determine whether alterations of L-type $\mathrm{Ca}^{2+}$-channel current that occurred in the ischemia-vulnerable neurons is a special characteristic of neurons destined to die or whether it is a common response of different types of postischemic neurons, including those (such as CA3 neurons) that go on to survive the insult, to ischemic stress. Single L-type calcium currents were recorded in hippocampal CA3 neurons prepared from controls $(n=18)$ and $48 \mathrm{~h}(n=26)$ after $15 \mathrm{~min}$ ischemia to determine whether a similar change occurs in pyramidal neurons of the CA3 region that are relatively resistant to transient ischemia using the same means (Fig. $2 C, D)$. Total L-type $\mathrm{Ca}^{2+}$-channel current in patches of CA3 neurons was not significantly different from controls at $48 \mathrm{~h}$ after reperfusion (control, $0.481 \pm$ 0.127 pA; 48 h, $0.509 \pm 0.108$ pA). Similarly, no significant changes were observed in the channel conductance (Fig. $2 H$ ) and open probability (control, $0.126 \pm 0.028$; $48 \mathrm{~h}, 0.133 \pm 0.03$ ) of single channels after ischemia.

\section{No change in the expression of $\mathrm{Ca}_{\mathrm{V} 1.2}$ and $\mathrm{Ca}_{\mathrm{V} 1.3}$ subunits in $\mathrm{CA} 1$ region after ischemia-reperfusion}

L-type voltage-sensitive $\mathrm{Ca}^{2+}$ channels are composed of up to four distinct subunits $(\alpha 1, \beta, \alpha 2-\delta$, and $\gamma$ ), and two $\alpha 1$ subunits $\left(\mathrm{Ca}_{\mathrm{V} 1.2}\right.$ and $\left.\mathrm{Ca}_{\mathrm{V} 1.3}\right)$, which reside in the membrane and form the pore of the channels, are the principal subunit of L-type calcium channels expressed in brains (Catterall, 2000). To assess the effect of global ischemia on $\mathrm{Ca}_{\mathrm{V}_{1.2}}$ and $\mathrm{Ca}_{\mathrm{V} 1.3}$ subunit expression, we performed Western blots of CA1 tissues from control and experimental animals at $24 \mathrm{~h}$ after ischemia with two subunitspecific antibodies. The experiment was performed at $24 \mathrm{~h}$ because there is no histologically detectable cell loss at this time, whereas L-type $\mathrm{Ca}^{2+}$-channel activity in vulnerable CA1 neurons displayed a marked downregulation at the same time after ischemia.

As shown in Figure 3, $A$ and $B$, Western blot studies using $\mathrm{Ca}_{\mathrm{V} 1.2}$ and $\mathrm{Ca}_{\mathrm{V} 1.3}$ antibodies revealed that no significant change in the levels of both $\mathrm{Ca}_{\mathrm{V} 1.2}$ and $\mathrm{Ca}_{\mathrm{V} 1.3}$ was observed at $24 \mathrm{~h}$ after ischemia-reperfusion compared with control. These results show that ischemia-reperfusion does not change $\mathrm{Ca}_{\mathrm{V} 1.2}$ and $\mathrm{Ca}_{\mathrm{V} 1.3}$ subunits expression specifically in vulnerable CA1 neurons.

However, the proportion of patches with channel openings was decreased at 24 and $48 \mathrm{~h}$ postischemia (Fig. $3 D$ ). This reduction of functional channels could be caused either by a redistribution of channels on the membrane or by a decrease in the number of functional channels expressed on the membrane. To clarify the former possibility, we examined the change in the distribution of $\mathrm{Ca}_{\mathrm{V} 1.2}$ and $\mathrm{Ca}_{\mathrm{V} 1.3}$ subunits on the $\mathrm{CA} 1$ pyramidal neurons after reperfusion. Cell bodies of pyramidal neurons in the CA1 areas of both control and ischemic rats are densely stained with the $\mathrm{Ca}_{\mathrm{V} 1.2}$ and $\mathrm{Ca}_{\mathrm{V} 1.3}$ subunit antibodies (Fig. $3 C$ ). In each case, there is an immunoreactivity band around the periphery of the cell soma and often an accumulation of immunoreactivity in the region in which the basal and apical dendrites emerge from the cell body. Forty-eight hours after reperfusion, regardless of $\mathrm{Ca}_{\mathrm{V} 1.2}$ or $\mathrm{Ca}_{\mathrm{V} 1.3}$, the pattern of immunostaining of the cell 
bodies of pyramidal cells is similar to that of the control group (Fig. 3C).

\section{Involvement of oxidation modulation in postischemic inhibition of L-type calcium channels}

Both native (Lacampagne et al., 1995) and recombinant ( $\mathrm{Hu}$ et al., 1997) L-type $\mathrm{Ca}^{2+}$ channels have also been shown to be modulated by oxidizing and reducing agents acting at thiol groups of cysteine residues in the channel protein. Within the hippocampus, there is a large elevation in superoxide radicals that is restricted to the vulnerable CA1 pyramidal layer $24 \mathrm{~h}$ after global ischemia and plays a role in the delayed ischemic death of hippocampal CA1 neurons (Chan et al., 1998). Superoxide radicals and other oxygen radicals would produce a more oxidizing extracellular environment under reperfusion conditions. Indeed, the change in redox state of $\mathrm{Ca}^{2+}$-activated potassium channels had been found in hippocampal CA1 neurons during reperfusion after ischemia (Gong et al., 2002). Thus, we assumed the redox state of L-type calcium channels in hippocampal CA1 pyramidal neuron might change during reperfusion after ischemia.

We next investigated redox modulation of L-type $\mathrm{Ca}^{2+}$ channel of CA1 neurons and whether such modulation is involved in a later persistent downregulation, after reperfusion after ischemic insult. The same protocol for isolation of L-type $\mathrm{Ca}^{2+}$ current as described in Figure 1 was used in the whole-cell recordings.

First, we compared the effects of bath application of redox couple 5,5' -dithio-bis (2-nitrobenzoic acid) (DTNB) and dithiothreitol (DTT), at a concentration of $2 \mathrm{mM}$ on $\mathrm{Ca}^{2+}$-channel currents in CA1 neurons dissociated from control and $24 \mathrm{~h}$ postischemic rats. Figure $4 A-D$ shows a typical time series of recordings (representative of 15 such recordings), made by repeatedly step-depolarizing cells from -50 to $-10 \mathrm{mV}$. The oxidizing agent DTNB markedly decreased the $\mathrm{Ca}^{2+}$-channel currents recorded in control CA1 neurons (Fig. 4A). Mean decrease in current amplitudes caused by DTNB was $45.7 \pm 4.9 \%(n=15 ; p<$ 0.01 ) (Fig. $4 E$ ). This inhibitory effect was fully reversible after removal of DTNB with control solution. However, only a moderate inhibition was observed in postischemic CA1 neurons (Fig. $4 C)$. The mean decrease in current amplitudes was $14.4 \pm 2.3 \%$ $(n=15, p<0.05)$ (Fig. $4 F)$. In contrast, the reducing agent DTT slightly increased the $\mathrm{Ca}^{2+}$-channel currents by $22.2 \pm 3.4 \%$ in the control neurons $(n=13 ; p<0.01)$ (Fig. $4 B, E)$ but significantly enhanced $\mathrm{Ca}^{2+}$-channel currents by $133.7 \pm 15.0 \%$ for postischemic neurons $(n=13$; $p<0.01)$ (Fig. $4 D, F)$, respectively. The results indicate that L-type $\mathrm{Ca}^{2+}$ channels in control CA1 neurons are in a more reduced state than postischemic channels (Fig. 4G).

To determine whether the effects of DTNB and DTT on control and postischemic $\mathrm{Ca}^{2+}$ channels are specific to these two reagents or result from changes in the redox state of the channel, actions of another redox couple, glutathione disulfide (GSSG) and glutathione (GSH), at the same dose of $2 \mathrm{~mm}$ were examined on $\mathrm{Ca}^{2+}$-channel currents of control and $24 \mathrm{~h}$ postischemic CA1 neurons. As DTNB and DTT, a similar result was obtained by GSSG and GSH. At a testing potential of $-10 \mathrm{mV}$, oxidizing agent GSSG had a markedly inhibitory effect on control $\mathrm{Ca}^{2+}$-channel currents $(62.3 \pm 9.2 \%$ inhibition, $n=12, p<0.01)$ (Fig. $4 E)$ but a moderate inhibitory action on postischemic channel currents (22.1 $\pm 3.2 \%$ inhibition, $n=13, p<0.01)$ (Fig. $4 F)$. Conversely, reducing agent GSH potentiated the control channel currents only by $13.8 \pm 3.0 \%(n=12$; $p<0.05)$ (Fig. $4 E)$, but to postischemic currents, potentiated by $105.4 \pm 18.3 \%(n=10 ; p<$ 0.01 ) (Fig. $4 F$ ). It is in Figure $4 G$ that oxidizing agents have a greater inhibition on control currents than postischemic, whereas reducing agents display a greater potentiation in the currents after ischemia when compared with controls.

We also examined the effects of redox couples on the singlechannel properties of L-type calcium currents in CA1 neurons dissociated from control and $24 \mathrm{~h}$ postischemic rats. As shown in supplemental Table S2 (available at www.jneurosci.org), regardless of oxidizing or reducing agents, there were no effects on the conductance of single L-type calcium channels in control and ischemic neurons ( $p>0.05 ; n=10$ for each group). However, the oxidizing agents had a greater inhibition on open frequency in control than in ischemic channels, whereas reducing agents 
A

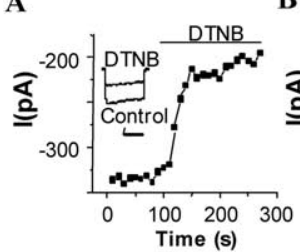

E

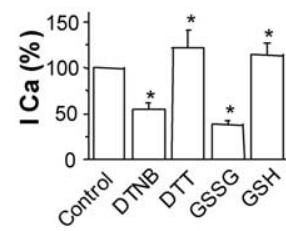

B

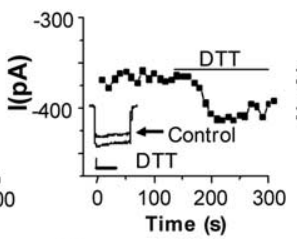

F
C

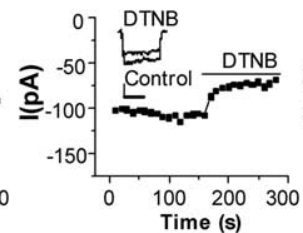

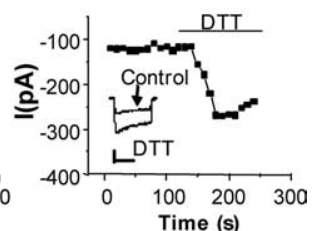

G

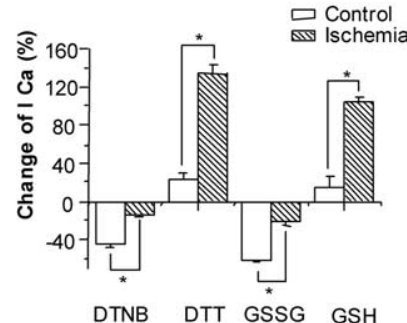

DTNB
H

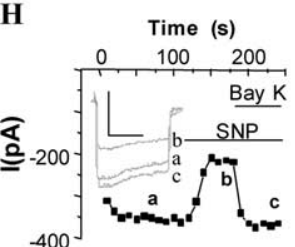

I

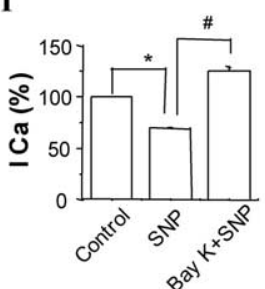

Figure 4. Effects of extracellular redox couple SNP and Bay K 8644 on whole-cell $\mathrm{Ca}^{2+}$-channel currents. $\boldsymbol{A}-\boldsymbol{D}$, Example of time-series plot of $\mathrm{Ca}^{2+}$-channel current amplitudes in control $(\boldsymbol{A}, \boldsymbol{B})$ and postischemic $(\boldsymbol{C}, \boldsymbol{D})$ CA1 neurons; each plotted point represents the current amplitude evoked by repeated step depolarizations ( $100 \mathrm{~ms}, 0.1 \mathrm{~Hz}$ ) to $-10 \mathrm{mV}$ from a holding potential of $-50 \mathrm{mV}$. For the period indicated by the horizontal bar, the perforate was exchanged for one containing 2 mм DTNB $(A, C)$ or 2 тм DTT $(\boldsymbol{B}, \boldsymbol{D})$. Inset shows example currents from this recording before and during exposure to agent as indicated. Calibration: 50 ms, $150 \mathrm{pA}(\boldsymbol{A}), 200 \mathrm{pA}(\boldsymbol{B})$, and $100 \mathrm{pA}(\boldsymbol{C}, \boldsymbol{D})$. $\boldsymbol{E}-\boldsymbol{G}$, Comparison of the effects of redox couples DTT and DTNB, GSH and GSSG on whole-cell $\mathrm{Ca}^{2+}$-channel currents in control and postischemic $C A 1$ neurons. Values are the mean \pm SEM of measurements made in $10-15$ neurons from at least four different rats. The asterisk indicates a statistically significant difference ( $p<0.05$ or 0.01 ; see Results). $\boldsymbol{E}$, Control. $\boldsymbol{F}, 24 \mathrm{~h}$ after ischemia. $\mathbf{G}$, Summary of percentage change caused by redox couples normalized to control in $\mathrm{Ca}^{2+}$ currents from control and postischemic neurons. $\boldsymbol{H}$, Time course for the effects of Bay K 8644 on the SNP-induced inhibition of the $\mathrm{Ca}^{2+}$ current in the cultured hippocampal neurons. Inset shows example of $\mathrm{Ca}^{2+}$-channel currents elicited by a step to $+10 \mathrm{mV} . \boldsymbol{a}$, Control; $\boldsymbol{b}, 200 \mu \mathrm{m}$ SNP; $\boldsymbol{c}, 200 \mu \mathrm{m}$ SNP plus $0.3 \mu \mathrm{m}$ Bay K 8644. Calibration: $50 \mathrm{~ms}, 400$ pA. I, Comparison of the effects of SNP and Bay K 8644 on the average $\mathrm{Ca}^{2+}$ currents at $+10 \mathrm{mV}(n=8) .{ }^{*} p<0.05$ versus control group; ${ }^{\#} p<0.05$ versus SNP group.

display a greater potentiation after reperfusion compared with controls. These results indicate a redox modification on the channel gating but not conductance.

\section{Downregulation of L-type $\mathrm{Ca}^{2+}$ channels contributes to neuronal cell death in vitro}

To test whether ischemic inhibition of L-type $\mathrm{Ca}^{2+}$ channels in hippocampal CA1 neurons is one of the mechanisms underlying delayed neuronal death after ischemia-reperfusion, we first mimicked the in vivo ischemia-induced inhibition of L-type calcium channels by using pharmacological manipulations in cultured hippocampal neurons. Nifedipine (a dihydopyridine L-type $\mathrm{Ca}^{2+}$-channel antagonist) treatment at a concentration of $10 \mu \mathrm{M}$ resulted in significant neuronal death compared with normal and ethanol controls. The neuronal surviving percentage was decreased to $71.27 \pm 3.00 \%$ after $1 \mathrm{~d}$ exposure to nifedipine $(p<$ 0.05 ) (Fig. $5 A$ ). In $0.1 \%$ ethanol-treated cultures, the percentage of surviving neurons was $111.75 \pm 4.06 \%(p>0.05$ compared with control).

To determine whether the effects of nifedipine described above are specific to L-type $\mathrm{Ca}^{2+}$ channels, another dihydopyridine L-type $\mathrm{Ca}^{2+}$-channel antagonist, nimodipine $(10 \mu \mathrm{M})$, $\mathrm{N}$-type channel antagonist $\omega$-conotoxin GVIA $(2 \mu \mathrm{M})$, and P/Qtype channel antagonist $\omega$-agatoxin IVA $(0.2 \mu \mathrm{M})$ were exam- ined. Nimodipine had a markedly inhibitory effect on hippocampal neuronal survival $(70.04 \pm 5.02 \%$; $p<0.01$ ) (Fig. $5 A)$. However, for $\omega$-conotoxin GVIA and $\omega$-agatoxin IVA, there was no significant effect on neuronal survival $(p>0.05)$ (Fig. 5A).

Nitric oxide (NO) production has clearly been linked to neurodegeneration in animal models of ischemia and in vitro cultured cells (Huang et al., 1994; Iadecola, 1997). Accordingly, we next mimicked the in vivo ischemia-induced pyramidal neuron death by using NO-related SNP-induced toxicity (Maiese et al., 1997) in cultured hippocampal neurons and test the effects of SNP and Bay K8644 on the currents.

Exposure to $200 \mu \mathrm{M}$ SNP resulted in a decrease in cell survival as shown by MTT, damaged to $53.70 \pm 2.2 \%(p<0.01 \mathrm{com}-$ pared with control) (Fig. 5B). But cotreatment of $200 \mu \mathrm{M}$ SNP and $10 \mu \mathrm{M}$ nifedipine did not lead an additional decrease in cell survival ( $p>0.05$ compared with $200 \mu \mathrm{M}$ SNP or $10 \mu \mathrm{M}$ nifedipine alone) (Fig. $5 B$ ). The mutual occlusion between the effects of SNP and blocking L-type channels, as expected for events in series, suggested an involvement of inhibition of L-type $\mathrm{Ca}^{2+}$ channel in the SNP-induced toxicity.

Furthermore, the MTT assay showed that the SNP-induced cell death of hippocampal cell cultures was significantly reduced when treatment was combined with $200 \mu \mathrm{M}$ SNP and specific L-type $\mathrm{Ca}^{2+}$-channel agonist $0.3 \mu \mathrm{M}$ Bay K 8644 (28.50\% for SNP plus Bay K 8644 vs $46.30 \%$ for SNP alone, an $\sim 40 \%$ net reduction of neuronal injury induced by SNP; $p<0.05$ ) (Fig. $5 B$ ). This indicated that enhancement of L-type $\mathrm{Ca}^{2+}$ channel markedly antagonizes the SNP-induced cell death. However, Bay K 8644 did not significantly does not affect cell survival by itself ( $p>0.05 ; 96.20 \pm 2.49$ vs normal control).

To confirm a direct inhibition on L-type $\mathrm{Ca}^{2+}$ currents by SNP and a restoration of the inhibited channels by L-type calcium-channel agonist, we examined the effects of SNP and Bay $\mathrm{K} 8644$ on the currents. Figure $4 H$ shows a representative time series of recordings and illustrates that SNP markedly decreased the $\mathrm{Ca}^{2+}$-channel currents recorded in cultured hippocampal neurons. Mean decrease in current amplitudes to $69.36 \pm 1.03 \%$ of the control $(n=8 ; p<0.05)$ (Fig. $4 I)$. This inhibitory effect was reversed by addition of Bay K 8644 ( $n=8$; $p<0.05$ compared with SNP alone) (Fig. $4 H, I)$.

The above results indicate that downregulation of L-type $\mathrm{Ca}^{2+}$ channels mediates SNP-induced neuronal cell death in culture.

Furthermore, to confirm whether inhibition of L-type $\mathrm{Ca}^{2+}$ channels in hippocampal CA1 neurons is a cause for ischemiareperfusion damage rather than a consequence of damage. We mimicked the in vivo ischemia-reperfusion damage using in vitro oxygen-glucose deprivation ischemic model. As shown in Figure 5, $C$ and $D$, treatment with Bay K 8644 after 1 h of reoxygenation 
significantly reduced cell death induced by oxygen-glucose deprivation compared with control cultures $(p<0.05)$.

Reduction of ischemic neuronal injury in rats treated with L-type $\mathrm{Ca}^{2+}$ channel agonist after $12 \mathrm{~h}$ of reperfusion

In the sham-operated group, there were no damaged neurons in the CA1 region, and the neuronal cell density of this region was $252.4 \pm 12.5$ (Fig. 6) $(n=6)$. As reported previously (Pulsinelli et al., 1982), a widespread damage to the CA1 region was observed in all of the control ischemic rats. The pyramidal neurons either presented a shrunken appearance with condensed nuclei and minimal cytoplasm or, in many instances, disappeared. The density of survival neurons in the CA1 region in this group was $<5 \%$ that of shamoperated group (Fig. 6). However, in rats treated with Bay K 8644 after 12 h of reperfusion, $\sim 20 \%$ neurons in CA1 field survived from ischemic insult (Fig. 6). Compared with the ischemic controls, the Bay K 8644-treated group showed a significant rescuing effect $(p<0.01)$.

\section{Discussion}

We demonstrate for the first time that L-type $\mathrm{Ca}^{2+}$ channel currents in CA1 neurons display a later persistent downregulation, after ischemic insult. However, all of these changes in postischemic CA1 neurons were not found in CA3 neurons. A selective change in neuronal excitability was also reported previously in postischemic hippocampal neurons in rats, in which the spike threshold and rheobase were changed in CA1 neurons but not in ischemia-resistant CA3 neurons (Gao et al., 1998, 1999). Combined with the facts that most of the CA1 neurons die after such severe ischemia, it is suggested that the changes in L-type $\mathrm{Ca}^{2+}$ channel currents in CA1 neurons may be associated with the cause, rather than the result, of postischemic neuronal injury.

The decrease of L-type $\mathrm{Ca}^{2+}$ current at the late phase of reperfusion is not completely consistent with the results of a previous autoradiographic binding study. Takizawa et al. (1994) has shown that after transient forebrain ischemia, the binding of the L-type calcium-channel antagonist $\left[{ }^{3} \mathrm{H}\right]$ nimodipine to brain is biophasic, a transient increase in a number of brain structures at $30 \mathrm{~min}$ and a second peak only in CA1, dentate, and striatum at $48 \mathrm{~h}$ of reperfusion. The differences in the results between the present and previous may be attributable to differences in technique. The recordings we performed by using patch-clamp techniques are from functional channels in pyramidal neurons, whereas the binding study could not distinguish between neuronal and glial, functional and nonfunctional channels. It has been shown that microglia invasion appears in the CA1 region, and new binding sites from internal membranes might be exposed to $\left[{ }^{3} \mathrm{H}\right]$ nimodipine resulting from cell lysis. Our results are in accord with a $\mathrm{Ca}^{2+}$ imaging study. Connor et al. (1999), using the versus $0 \mathrm{GD}$ group.
C

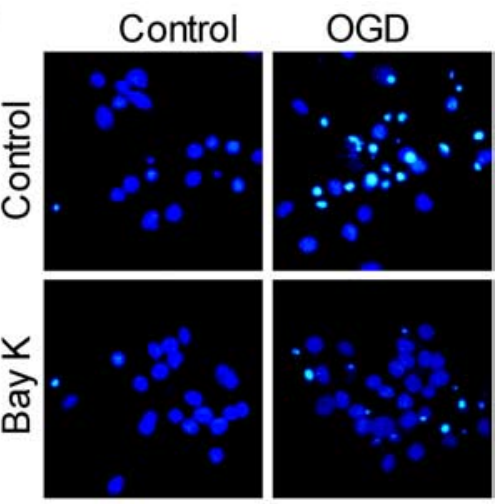

D

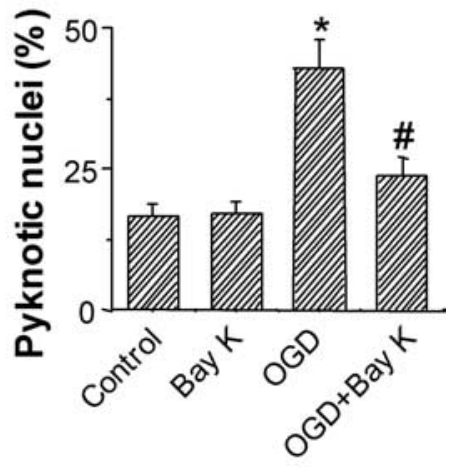

Figure 5. Downregulation of $\mathrm{L}$-type $\mathrm{Ca}^{2+}$ channels contributes to hippocampal neuronal cell death in vitro. $\boldsymbol{A}, \boldsymbol{B}$, Summary of Bay K 8644 significantly reduced apoptotic cell death compared with control cultures. ${ }^{*} p<0.05$ versus control group; ${ }^{*} p<0.05$

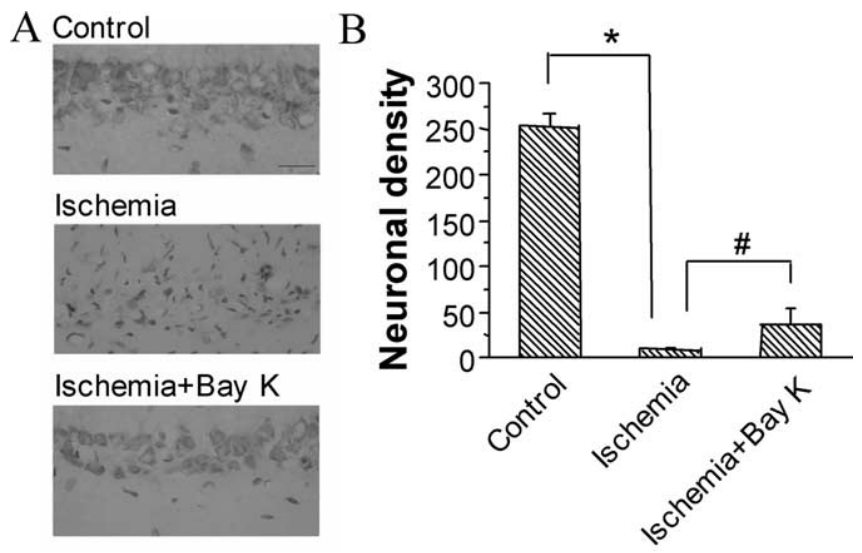

Figure 6. Significant reduction of ischemic neuronal injury in rats treated with L-type $\mathrm{Ca}^{2+}$ channel agonist Bay K 8644 after 12 h of reperfusion. $\boldsymbol{A}$, Effect of Bay K 8644 on the ischemic damage of CA1 pyramidal neurons in rats. Bay $\mathrm{K} 8644$ (0.2 mM) was delivered intracerebroventricularly with osmotic minipumps at $0.5 \mu \mathrm{l} / \mathrm{h}$ after $12 \mathrm{~h}$ of reperfusion for $3 \mathrm{~d}$. Scale bar, $20 \mu \mathrm{m}$. $\boldsymbol{B}$, Neuronal density (number of intact pyramidal cells per $1 \mathrm{~mm}$ linear length) in the (A1 field. $n=6$ for each group. ${ }^{*} p<0.01$ compared with sham-operated control. ${ }^{\#} p<0.01$ compared with ischemic control. 
$\mathrm{Ca}^{2+}$ spike as a measure of $\mathrm{Ca}^{2+}$ influx, reported a striking reduction in the magnitude of $\mathrm{Ca}^{2+}$ transients mediated by voltage-gated $\mathrm{Ca}^{2+}$ entry in CA1, but not CA3, neurons 2 and $3 \mathrm{~d}$ after a 5 min ischemic insult in gerbils (Shuttleworth et al., 2000). Basal $\mathrm{Ca}^{2+}$ levels were also found to be normal to subnormal. The timing match between the decrease in L-type calciumchannel currents and the appearance of the histological signs of CA1 neuronal death suggests a decisive role of the downregulation in L-type calcium channel in the delayed neuronal death of hippocampus after ischemia.

Our single-channel analysis showing a decrease in open probability without alteration of unitary conductance suggest that one possible mechanism underlying the alterations of L-type calcium-channel currents is the changes in the number, the distribution, and/or the properties of functionally available L-type calcium channels on postischemic CA1 neurons. One possibility is that ischemia may induce the degradation of primary channels at a later stage of reperfusion in CA1 neurons. Actually, it has been shown that the mRNA and protein levels of L-type calcium channel is changed during aging in cultured hippocampal neurons (Porter et al., 1997), implying that the expression of this kind of channel could be also modulated by ischemia. However, our Western blot evidenced that the downregulation of L-type calcium channels in postischemic CA1 neurons was not attributable to alteration in the channel protein expression. Consistent with our result, Westenbroek et al. (1998) found that there is no change in the distribution or level of expression of L- or N-type $\mathrm{Ca}^{2+}$ channels in neurons after ischemia. Second, ischemia may modulate the previously functional channels. That is to say, the channel availability and properties including open time and open frequency may be altered after ischemia. Our results, showing a decrease in the patches with channel openings but no obvious change in the distribution of two channel subunits on postischemic CA1 neurons, support the assumption of a reduced number of functionally available channels.

The present study has explored the redox mechanism and found that extracellular application of the oxidizing agents DTNB and GSSG has a greater inhibition on calcium-channel currents recorded in normal CA1 neurons than those in postischemic neurons, whereas the reducing agents DTT and GSH increase the calcium-channel currents more in postischemic CA1 neurons compared with control neurons. These results indicate that L-type calcium channels in CA1 pyramidal neurons can be modulated by extracellular redox potential and that modulation of L-type calcium channels by oxidative stress might contribute to the postischemic electrophysiological alterations of CA1 pyramidal neurons.

The inhibitory effect of calcium currents by GSSG has potentially important physiological and pathological implications. GSH is a natural endogenous antioxidant compound. Under physiological conditions, GSH normally present at 1-2 mM external concentration in the CNS (Slivka et al., 1987). Under some pathological circumstance such as reperfusion after ischemia, an accumulation of a mass of oxygen free radicals in hippocampal CA1 neurons (Chan et al., 1998) can convert GSH to the oxidized form (GSSG) (Sucher and Lipton, 1991) and alters the GSH/ GSSG ratio (Chan et al., 1998), suggesting an increased oxidative potential within postischemic neurons. The present study shows that GSSG suppresses L-type calcium-channel currents in normal neurons, whereas GSH provides an enhancement in postischemic currents. Hence, postischemic inhibition of L-type calcium channels may be caused by an increase in cellular oxidation potential in CA1 pyramidal neurons after ischemia.
Moreover, changes in activity or translocation of protein kinases and phosphatases are observed in hippocampal CA1 neurons after ischemia (Lipton, 1999; Wang et al., 2003; Gao et al., 2005; Shamloo et al., 2005) and have been proposed to account for ischemical modulation of ion channels. It is unlikely that a single unifying mechanism accounts for such effects.

The dihydropyridines nifedipine or nimodipine block the survival of hippocampal neurons and specific L-type $\mathrm{Ca}^{2+}$-channel agonist Bay K8644 antagonizes the SNP-induced cell death. In accord with our results, it has been demonstrated that prolonged exposure to various antagonists of L-type voltage-gated calcium channels induces several kinds of cultured neurons to undergo apoptosis (Lee et al., 1999). In addition, activating L-type voltagegated calcium channels can attenuate apoptosis of cultured neurons or improve the survival of sympathetic neurons deprived of nerve growth factor (Johnson and Deckwerth, 1993; Lee et al., 1999). In contrast, the specific antagonists of $\mathrm{N}$ - and $\mathrm{P} / \mathrm{Q}$-type channels have no apparent effects on neuronal survival. More importantly, L-type calcium-channel agonist applied after reoxygenation or reperfusion significantly reduces neuronal injury in in vitro oxygen-glucose deprivation ischemic model and in animals subjected to forebrain ischemia and reperfusion. Therefore, we suggest that inhibition of L-type calcium currents may specifically contribute to the delayed neuronal death in CA1 region of hippocampus after transient forebrain ischemia. Compared with the in vitro effects, Bay K 8644 provides less neuroprotection in ischemic animals. One possibility for this is that contributors to neuronal death in ischemic animals are more than those in purely cultured neurons, such as involvement of activated glial cells in in vivo neuronal injury after ischemia and reperfusion (Nedergaard and Dirnagl, 2005). It is also possible that higher concentrations of Bay K 8644 or different exposure time windows would have greater efficacy in vivo.

The activity of L-type calcium channel is linked to neuronal survival and death via transducing calcium-regulated signaling events to the nucleus. These modulate the expression of survival genes such as those encoding c-Fos, BDNF, and Bcl-2 (Murphy et al., 1991; Bito et al., 1996; Catterall, 2000; Dolmetsch et al., 2001; West et al., 2001; Weick et al., 2003; Zhou et al., 2004). The survival signaling from the L-type $\mathrm{Ca}^{2+}$ channel to nucleus has been proposed to be mediated by interactions with signaling molecules. It has been reported that the binding of $\mathrm{CaM}\left(\mathrm{Ca}^{2+}\right.$ calmodulin) to the L-type $\mathrm{Ca}^{2+}$ channel is necessary for activation of the Ras/MAPK (mitogen-activated protein kinase) pathway, which conveys local $\mathrm{Ca}^{2+}$ signals from the mouth of the L-type $\mathrm{Ca}^{2+}$ channel to the nucleus (Dolmetsch et al., 2001). In addition, Weick et al. (2003) found that interactions with PDZ (postsynaptic density-95/Discs large/Zona occludens-1) domain proteins are necessary for L-type calcium channels to effectively activate CREB and CRE-mediated gene expression. Thus, it is reasonable to presume that a downregulation of L-type calcium channels in ischemic neurons may weaken its interaction with intracellular partners leading to a reduction of those gene expression and results in the delayed neuronal death.

It has been known that there is a $\mathrm{Ca}^{2+}$ overload in destined death neurons at the period of ischemia and immediately after reperfusion (Andine et al., 1992; Silver and Erecinska, 1992). $\mathrm{Ca}^{2+}$ overload triggers the elevation of superoxide radicals and other oxygen radicals (Chan et al., 1998), and then, according to our results, the accumulated oxygen radicals may inhibit the L-type calcium currents at a later period of reperfusion. Inhibition of the L-type calcium currents via reducing expression of a group of $\mathrm{Ca}^{2+}$-regulated genes results in the neuronal 
death finally. Therefore, we presume that $\mathrm{Ca}^{2+}$ overload at the period of ischemia and immediately after reperfusion is only a trigger, but the later persistent downregulation of L-type calcium channels may be one of the executors of delayed neuronal death.

\section{References}

Andine P, Jacobson I, Hagberg H (1992) Enhanced calcium uptake by CA1 pyramidal cell dendrites in the postischemic phase despite subnormal evoked field potentials: excitatory amino acid receptor dependency and relationship to neuronal damage. J Cereb Blood Flow Metab 12:773-783.

Bano D, Young KW, Guerin CJ, Lefeuvre R, Rothwell NJ, Naldini L, Rizzuto R, Carafoli E, Nicotera P (2005) Cleavage of the plasma membrane $\mathrm{Na}+/ \mathrm{Ca} 2+$ exchanger in excitotoxicity. Cell 28:275-285.

Berridge MJ (1998) Neuronal calcium signaling. Neuron 21:13-26.

Bito H, Deisseroth K, Tsien RW (1996) CREB phosphorylation and dephosphorylation: a Ca2+- and stimulus duration-dependent switch for hippocampal gene expression. Cell 87:1203-1214.

Burley JR, Dolphin AC (2000) Overlapping selectivity of neurotoxin and dihydropyridine calcium channel blockers in cerebellar granule neurones. Neuropharmacology 39:1740-1755.

Catterall WA (2000) Structure and regulation of voltage-gated Ca2 + channels. Annu Rev Cell Dev Biol 16:521-555.

Chan PH, Kawase M, Murakami K, Chen SF, Li Y, Calagui B, Reola L, Carlson E, Epstein CJ (1998) Overexpression of SOD1 in transgenic rats protects vulnerable neurons against ischemic damage after global cerebral ischemia and reperfusion. J Neurosci 18:8292-8299.

Chen KC, Blalock EM, Thibault O, Kaminker P, Landfield PW (2000) Expression of alpha 1D subunit mRNA is correlated with L-type Ca2+ channel activity in single neurons of hippocampal "zipper" slices. Proc Natl Acad Sci USA 97:4357-4362.

Choi DW (1995) Calcium: still center-stage in hypoxic-ischemic neuronal death. Trends Neurosci 18:58-60.

Connor JA, Razani-Boroujerdi S, Greenwood AC, Cormier RJ, Petrozzino JJ, Lin RC (1999) Reduced voltage-dependent $\mathrm{Ca}^{2+}$ signaling in CA1 neurons after brief ischemia in gerbils. J Neurophysiol 81:299-306.

Culmsee C, Zhu C, Landshamer S, Becattin B, Wagner E, Pellechia M, Blomgren K, Plesnila N (2005) Apoptosis-inducing factor triggered by poly(ADP-Ribose) polymerase and Bid mediates neuronal cell death after oxygen-glucose deprivation and focal cerebral ischemia. J Neurosci 25:10262-10272.

Dolmetsch RE, Pajvani U, Fife K, Spotts JM, Greenberg ME (2001) Signaling to the nucleus by an L-type calcium channel-calmodulin complex through the MAP kinase pathway. Science 294:333-339.

Fisher RE, Gray R, Johnston D (1990) Properties and distribution of single voltage-gated calcium channels in adult hippocampal neurons. J Neurophysiol 64:91-104.

Gao J, Duan B, Wang D, Deng X, Zhang G, Xu L, Xu T (2005) Coupling between NMDA receptor and acid-sensing ion channel contributes to ischemic neuronal death. Neuron 48:635-646.

Gao TM, Howard EM, Xu ZC (1998) Transient neurophysiological changes in CA3 neurons and dentate granule cells after severe forebrain ischemia in vivo. J Neurophysiol 80:2860-2869.

Gao TM, Pulsinelli WA, Xu ZC (1999) Changes in membrane properties of CA1 pyramidal neurons after transient forebrain ischemia in vivo. Neuroscience 90:771-780.

Gong L, Gao TM, Li X, Huang H, Tong Z (2000) Enhancement in activities of large conductance calcium-activated potassium channels in CA1 pyramidal neurons of rat hippocampus after transient forebrain ischemia. Brain Res 884:147-154.

Gong LW, Gao TM, Huang H, Zhuang ZY, Tong Z (2002) Transient forebrain ischemia induces persistent hyperactivity of large conductance $\mathrm{Ca}^{2+}$-activated potassium channels via oxidation modulation in rat hippocampal CA1 pyramidal neurons. Eur J Neurosci 15:779-783.

Hu H, Chiamvimonvat N, Yamagishi T, Marban E (1997) Direct inhibition of expressed cardiac L-type $\mathrm{Ca}^{2+}$ channels by S-nitrosothiol nitric oxide donors. Circ Res 81:742-752.

Huang Z, Huang PL, Panahian N, Dalkara T, Fishman MC, Moskowitz MA (1994) Effects of cerebral ischemia in mice deficient in neuronal nitric oxide synthase. Science 265:1883-1885.
Iadecola C (1997) Bright and dark sides of nitric oxide in ischemic brain injury. Trends Neurosci 20:132-139.

Ji RR, Bose CM, Lesuisse C, Qiu D, Huang JC, Zhang Q, Rupp F (1998) Specific agrin isoforms induce cAMP response element binding protein phosphorylation in hippocampal neurons. J Neurosci 18:9695-9702.

Johnson Jr EM, Deckwerth TL (1993) Molecular mechanisms of developmental neuronal death. Annu Rev Neurosci 16:31-46.

Kirino T, Tamura A, Sano K (1984) Delayed neuronal death in the rat hippocampus following transient forebrain ischemia. Acta Neuropathol (Berl) 64:139-147.

Kristian T, Siesjo BK (1998) Calcium in ischemic cell death. Stroke 29:705-718.

Lacampagne A, Duittoz A, Bolanos P, Peineau N, Argibay JA (1995) Effect of sulfhydryl oxidation on ionic and gating currents associated with L-type calcium channels in isolated guinea-pig ventricular myocytes. Cardiovasc Res 30:799-806.

Landfield PW (1996) Aging-related increase in hippocampal calcium channels. Life Sci 59:399-404.

Lee JM, Zipfel GJ, Choi DW (1999) The changing landscape of ischaemic brain injury mechanisms. Nature 399:A7-14.

Li XM, Li JG, Hu P, Gao TM (2002) Biphasic changes in L-type $\mathrm{Ca}^{2+}$ channel currents of rat hippocampal CA1 neurons after transient forebrain ischemia. Soc Neurosci Abstr 28:95.2.

Li XM, Bai XC, Qin LN, Huang H, Xiao ZJ, Gao TM (2003a) Neuroprotective effects of Buyang Huanwu Decoction on neuronal injury in hippocampus after transient forebrain ischemia in rats. Neurosci Lett 346:29-32.

Li XM, Li JG, Wang Y, Yang JM, Gao TM (2003b) Redox modulation involves in the later persistent down-regulation of L-type calcium currents in CA1 pyramidal neurons of rat hippocampus after transient forebrain ischemia. Soc Neurosci Abstr 29:308.9.

Lipton P (1999) Ischemic cell death in brain neurons. Physiol Rev 79:1431-1568.

Maiese K, TenBroeke M, Kue I (1997) Neuroprotection of lubeluzole is mediated through the signal transduction pathways of nitric oxide. J Neurochem 68:710-714.

Murphy TH, Worley PF, Baraban JM (1991) L-type voltage-sensitive calcium channels mediate synaptic activation of immediate early genes. Neuron 7:625-635.

Nedergaard M, Dirnagl U (2005) Role of glial cells in cerebral ischemia. Glia 50:281-286.

Norris CM, Blalock EM, Chen KC, Porter NM, Landfield PW (2002) Calcineurin enhances L-type $\mathrm{Ca}^{2+}$ channel activity in hippocampal neurons: increased effect with age in culture. Neuroscience 110:213-225.

Porter NM, Thibault O, Thibault V, Chen KC, Landfield PW (1997) Calcium channel density and hippocampal cell death with age in long-term culture. J Neurosci 17:5629-5639.

Pulsinelli WA, Brierley JB (1979) A new model of bilateral hemispheric ischemia in the unanesthetized rat. Stroke 10:267-272.

Pulsinelli WA, Brierley JB, Plum F (1982) Temporal profile of neuronal damage in a model of transient forebrain ischemia. Ann Neurol 11:491-498.

Regan LJ, Sah DW, Bean BP (1991) $\mathrm{Ca}^{2+}$ channels in rat central and peripheral neurons: high-threshold current resistant to dihydropyridine blockers and omega-conotoxin. Neuron 6:269-280.

Shamloo M, Soriano L, Wieloch T, Nikolich K, Urfer R, Oksenberg D (2005) Death-associated protein kinase is activated by dephosphorylation in response to cerebral ischemia. J Biol Chem 280:42290-42299.

Shuttleworth CW, Greenwood AC, Connor JA (2000) $\mathrm{Ca}^{2+}$ signaling in gerbil CA3 hippocampal neurons following transient in vivo ischemia. Neurosci Lett 286:75-78.

Silver IA, Erecinska M (1992) Ion homeostasis in rat brain in vivo: intraand extracellular $\left[\mathrm{Ca}^{2+}\right]$ and $\left[\mathrm{H}^{+}\right]$in the hippocampus during recovery from short-term, transient ischemia. J Cereb Blood Flow Metab 12:759-772.

Slivka A, Spina MB, Cohen G (1987) Reduced and oxidized glutathione in human and monkey brain. Neurosci Lett 74:112-118.

Sochivko D, Chen J, Becker A, Beck H (2003) Blocker-resistant Ca2 + currents in rat CA1 hippocampal pyramidal neurons. Neuroscience 116:629-638.

Sucher NJ, Lipton SA (1991) Redox modulatory site of the NMDA receptor- 
-channel complex: regulation by oxidized glutathione. J Neurosci Res 30:582-591.

Takizawa S, Hogan MJ, Buchan AM, Hakim AM (1994) In vivo binding of $[3 \mathrm{H}]$ nimodipine in rat brain after transient forebrain ischemia. J Cereb Blood Flow Metab 14:397-405.

Thibault O, Landfield PW (1996) Increase in single L-type calcium channels in hippocampal neurons during aging. Science 272:1017-1020.

Wang J, Liu S, Fu Y, Wang JH, Lu Y (2003) Cdk5 activation induces hippocampal CA1 cell death by directly phosphorylating NMDA receptors. Nat Neurosci 6:1039-1047.

Weick JP, Groth RD, Isaksen AL, Mermelstein PG (2003) Interactions with PDZ proteins are required for L-type calcium channels to activate cAMP response element-binding protein-dependent gene expression. J Neurosci 23:3446-3456.

West AE, Chen WG, Dalva MB, Dolmetsch RE, Kornhauser JM, Shaywitz AJ, Takasu MA, Tao X, Greenberg ME (2001) Calcium regulation of neuronal gene expression. Proc Natl Acad Sci USA 98:11024-11031.

Westenbroek RE, Bausch SB, Lin RC, Franck JE, Noebels JL, Catterall WA (1998) Upregulation of L-type $\mathrm{Ca}^{2+}$ channels in reactive astrocytes after brain injury, hypomyelination, and ischemia. J Neurosci 18:2321-2334.

Zhou H, Kim SA, Kirk EA, Tippens AL, Sun H, Haeseleer F, Lee A (2004) $\mathrm{Ca}^{2+}$-binding protein-1 facilitates and forms a postsynaptic complex with Cav1.2 (L-type) $\mathrm{Ca}^{2+}$ channels. J Neurosci 24:4698-4708. 